\title{
POSSIBILITIES OF CADMIUM REDUCING IN ANIMAL FOOD BY SOIL, LIMING AND GENOTYPE
}

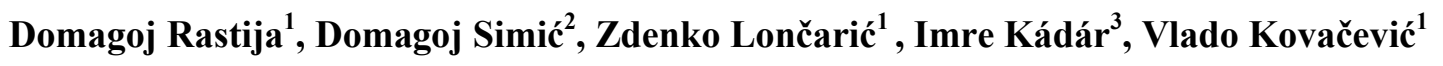 \\ ${ }^{1}$ University J. J. Strossmayer in Osijek, Faculty of Agriculture, 31000 Osijek, Croatia \\ ${ }^{2}$ Agricultural Institute Osijek, Južno predgradje 17, 31000 Osijek, Croatia \\ ${ }^{3}$ Research Institute for Soil Science and Agricultural Chemistry, 1022 Budapest, Hungary \\ domagoj.rastija@pfos.hr
}

\begin{abstract}
The harmful elements monitoring, particularly $\mathrm{Cd}$, have become important for environmental protection. Very low concentrations of $\mathrm{Cd}$ in dry matter of plant tissues were found under non-polluted environment of the eastern Croatia. With that regard, differences were found in maize leaves as affected by soil type (averages of ten hybrids) from 0.09 and $0.14 \mathrm{ppm} \mathrm{Cd}$, for acid and neutral soil (pH in $\mathrm{KCl} 4.10$ and 6.81), as well as among genotypes from 0.07 to $0.18 \mathrm{ppm} \mathrm{Cd}$. Grain-Cd in maize were considerably lower and below detection limit ( $<0.02 \mathrm{ppm} \mathrm{Cd})$. Liming is usual recommended management practice for acid soils fertility improvement. Beside effects on crop yields, liming is useful management practice for decreasing $\mathrm{Cd}$ transfer into food chain. In the liming experiment on acid soil, we found in maize leaves (2-year averages) 0.17 and $0.09 \mathrm{mg} \mathrm{Cd} \mathrm{kg}^{-1}$, for control and averages of four liming treatments, respectively. Differences were found also between two growing seasons ( 0.10 and $0.07 \mathrm{ppm} \mathrm{Cd}$, respectively). Also, considerably impact of liming on decreases of $\mathrm{Cd}$ in alfalfa hay was found $(0.113$ and $0.047 \mathrm{ppm} \mathrm{Cd}$, for 0 and $20 \mathrm{t} \cdot \mathrm{ha}^{-1}$ of lime).
\end{abstract}

Key words: cadmium; maize; alfalfa hay; soybean; soil effect; genotype effect; liming effect

\section{МОЖНОСТИ ЗА НАМАЛУВАЊЕ НА КАДМИУМОТ ВО ХРАНАТА ЗА ЖИВОТНИ ПРЕКУ ПОЧВАТА, КАЛЦИФИКАЦИЈАТА И ГЕНОТИПОТ}

\begin{abstract}
Мониторингот на штетните елементи, особено Сd (кадмиумот), стана важен за заштитата на животната средина. Многу ниски концентрации на Сd во сувата материја на растителното ткиво беа утврдени во незагадена животна средина во источна Хрватска. Во овој поглед има разлики кај листовите на пченка во зависност од типот на почвата (просечно десет хибриди) од 0,09 и 0,14 ppm Cd за кисела и неутрална почва (pH во $\mathrm{KCl} 4,10$ и 6,81$)$, како и меѓу генотиповите од 0,07 до 0,18 ppm Cd. Концентрацијата на кадмиум во пченкарното зрно беше значително пониска и под лимитот на детекција ( $<0,02 \mathrm{ppm} \mathrm{Cd})$. Калцификацијата е вообичаена практика која се препорачува за подобрување на плодноста на киселите почви. Покрај ефектот врз приносот, калцификацијата е корисна и за намалување на трансферот на $\mathrm{Cd}$ во синџирот на исхрана. Во експериментот за калцификација на кисела почва, во пченкарните листови (во просек 2 години) утврдивме 0,17 и 0,09 $\mathrm{mg} \mathrm{Cd} \mathrm{kg}$, за контрола и просечно четири третмани на калцификација, содветно. Исто така, разлики утврдивме и помеѓу двете развојни сезони (0,10 и 0,07 ppm Cd, соодветно). Покрај ова, калцификацијата има значајно влијание и за намалување на Сd во сеното од луцерка $\left(0,113\right.$ и $0,047 \mathrm{ppm} \mathrm{Cd}$ за 0 и 20 t·ha ${ }^{-1}$ вар).
\end{abstract}

Клучни зборови: кадмиум; пченка; сено од луцерка; соја; ефект на почва; ефект на генотип; ефект на калцификација

\section{INTRODUCTION}

The harmful elements monitoring, particularly $\mathrm{Cd}$, have become important for environmental protection (Pinto et al., 2004; Godt et al., 2006; Stingu et al., 2011; Kadar and Koncz, 2000; Kadar et al., 1998, 2002). Critical concentrations of $\mathrm{Cd}$ in plants are between 5 and $10 \mathrm{mg} \mathrm{Cd} \mathrm{kg}$ and in diet 
of animals between 0.5 and $1 \mathrm{mg} \mathrm{Cd} \mathrm{kg}$ (Bergman 1992; Mengel and Kirkby, 2001). The tolera-

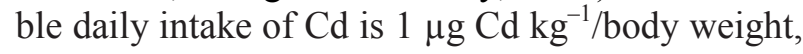
an equivalent to a daily intake of $70 \mu \mathrm{g} \mathrm{Cd}$ for an adult of $70 \mathrm{~kg}$.

Soil pollutions with $\mathrm{Cd}$ in Croatia are mainly low and $\mathrm{Cd}$ concentrations in the field crops (Kovačević et al., 2002, 2008; Bukvić et al., 2003) and excessive concentrations of $\mathrm{Cd}$ were found mostly in soils of urban areas (Lončarić et al., 2012a, 2012b).

The objective of this study was review of some research of cadmium status in plants as affected by genotype (hereditary effects) and by soil properties including improvement of soil by liming (environmental effects) under non-polluted environment of the eastern Croatia.

\section{MATERIAL AND METHODS}

Four field experiments were performed in eastern Croatia with aim of testing adaptability of maize hybrids to different soils and response of field crops to liming. The experiments were conducted in four replicates. Basic plot measured 14 $\mathrm{m}^{2}$ and $64 \mathrm{~m}^{2}$, for two experiments of hybrids and liming experiment, respectively. Leaves of maize for chemical analysis were taken at silking stage while grain samples were collected at maturity. The uppermost full-developed leaves of soybean and tobacco were taken at the beginning of anthesis (soybean) and at the mid-season (tobacco). The aboveground part of alfalfa were collected during the second cutting in July.

The total amounts of cadmium in plant materials were determined using ICP after their microwave digestion by concentrated $\mathrm{HNO}_{3}+\mathrm{H}_{2} \mathrm{O}_{2}$. Determinations were made by Jobin-Yvon Ultrace 238 ICP-OES spectrometer in the Research Institute for Soil Science and Agricultural Chemistry (RISSAC) in Budapest. The data were statistically analyzed by ANOVA and treatment means were compared using $t$-test and LSD at 0.05 probability level.

The experiment A: Ten maize hybrids were grown on two soil types (acid and neutral soil) mutually distanced about $2 \mathrm{~km}$ by air-line in Sopje, east Croatia, during the 1997 growing season. Most results of this experiment were shown in previous studies (Antunović et al., 2002, 2003, 2004; Kovačević et al., 2004; Kovačević et al., 2012b).
The experiment B: Ten maize hybrids were grown on two soils of moderate fertility (calcaric fluvisol and pseudogley) at eastern part of Sava valley in Croatia during the 1998 growing season. The experiments were conducted in four replicates and experimental plot was $14 \mathrm{~m}^{2}$. Results of this experiment were shown in previous studies (Kovačević et al., 2002; Bukvić et al., 2003; Kovačević et al., 2012b).

The experiment C: Stationary field experiment of liming with Carbocalk (by-product from sugar factory) on acid soil in the east Croatia started in autumn 2000. Carbocalk is very rich in calcium $(34.4 \%)$ and contain also $\mathrm{Mg}(1.1 \%)$, phosphorus $(0.5 \%)$, aluminum $(0.4 \%)$, iron and sulfur $(0.3 \%)$. Some results of this experiment were shown in the previous studies (Jurkovic et al., 2008; Kovačević et al., 2006, 2010, 2012a, 2012b; Tursić et al., 2008; Rastija et al., 2012c; Kovačević and Lončarić, 2014).

The experiment D: Increasing rates of dolomite powder $\left(0,10,20,30\right.$ and $\left.40 \mathrm{tha}^{-1}\right)$ were applied in the autumn of 2004 on acid soil $(\mathrm{pH}$ in $\mathrm{KCl} \mathrm{5.16)}$ in the middle Croatia. Majority results of the experiment were shown in the previous studies (Popović et al., 2007; Rastija et al., 2012a).

\section{RESULTS AND DISCUSSION}

Soil properties, mainly $\mathrm{pH}$ differences, considerable affected $\mathrm{Cd}$ concentrations in maize leaves (means 0.09 and $0.14 \mathrm{mg} \mathrm{Cd} \mathrm{kg}^{-1}$, for fluvisol and pseudogley, respectively). However, hereditary effects were stronger factor because under identical environmental conditions, differences among ten maize hybrids were from 0.07 to $0.18 \mathrm{mg} \mathrm{Cd} \mathrm{kg}^{-1}$. With that regard, three hybrids (OsSK332, OsSK445 and OsSK382) separated from remaining seven hybrids by the higher $\mathrm{Cd}$ concentrations (means 0.16 and $0.09 \mathrm{mg} \mathrm{Cd} \mathrm{kg}$, respectively). Grain-Cd was considerably lower compared to leaf-Cd and below detection limit of the applied analytical method (Table 1).

Also, under conditions of the experiment B (Table 2), both soil and heredity factors affected $\mathrm{Cd}$ status in maize leaves.

$\mathrm{Cd}$ concentrations in maize leaves were higher under conditions of pseudogely compared to calcaric fluvisol (means 0.16 and $0.10 \mathrm{mg} \mathrm{Cd} \mathrm{kg}^{-1}$, respectively), probably because of acid reaction of pseudogley. Considerable influences of inheritance 
on $\mathrm{Cd}$ status in maize leaves were found. In four hybrids (OsSK382, OsSK458, OsSK497 and OsSK552) Cd contents were lower than $0.1 \mathrm{mg} \mathrm{kg}^{-1}$ $\mathrm{Cd}$ (mean $0.081 \mathrm{mg} \mathrm{kg}^{-1} \mathrm{Cd}$ ), while in two hybrids (OsSK568exp and OsSK602) they were above 0.2 $\mathrm{mg} \mathrm{kg}{ }^{-1} \mathrm{Cd}$ (mean 0.263).

In general, amelioration of soil by liming with carbocalk considerably affected $\mathrm{Cd}$ concentrations in plants (Table 3). For example, as affected by liming, leaf-Cd were decreased from 0.17 to 0.08 $\mathrm{mg} \mathrm{Cd} \mathrm{kg}{ }^{-1}$ (maize), from 3.2 to $0.14 \mathrm{mg} \mathrm{Cd} \mathrm{kg}^{-1}$ (tobacco) and from 0.50 to $0.5 \mathrm{mg} \mathrm{Cd} \mathrm{kg}{ }^{-1}$ (soybean), for the control and averages of four limed treatments, respectively. Regarding this, considerable effect of the growing season (year) were found (Table 3).

Also, liming by dolomite considerably affected Cd status of alfalfa hay as follows: 0.113 and $0.505 \mathrm{mg} \mathrm{Cd} \mathrm{kg}$, for the control and three limed treatments, respectively (Table 4 ).

Table 1

\section{Soil and genotype effects on cadmium status in maize leaves \\ (Bukvić et al., 2003)}

\begin{tabular}{|c|c|c|c|c|c|c|c|c|c|c|c|}
\hline \multicolumn{12}{|c|}{ The experiment A: Soil and genotype effects on cadmium concentrations in maize } \\
\hline \multicolumn{12}{|c|}{ Maize hybrid (the factor B) } \\
\hline Soil & & & & & & & & & & & A \\
\hline (A) & 332 & 373 & 382 & 425 & 426 & 427 & 445 & 552 & 554 & 622 & effect \\
\hline \multicolumn{12}{|c|}{ Cadmium status in leaves (the ear-leaf at silking stage: $\mathrm{mg} \mathrm{Cd} \mathrm{kg}^{-1}$ in dry matter ) } \\
\hline A1 & 0.14 & 0.06 & 0.10 & 0.06 & 0.06 & 0.07 & 0.15 & 0.07 & 0.07 & 0.07 & 0.09 \\
\hline A2 & 0.22 & 0.10 & 0.17 & 0.11 & 0.09 & 0.11 & 0.18 & 0.14 & 0.15 & 0.08 & 0.14 \\
\hline B effect & 0.18 & 0.08 & 0.13 & 0.09 & 0.08 & 0.08 & 0.16 & 0.10 & 0.11 & 0.07 & \\
\hline
\end{tabular}

Statistical analysis (LSD 5\%)

A: 0.02

B: 0.04

AB: 0.06

Cadmium status in grain at maturity:

Below detection limit of the method $\left(<0.02 \mathrm{mg} \mathrm{Cd} \mathrm{kg}^{-1}\right.$ on dry matter basis)

A1: Sopje fluvisol ( $\mathrm{pH}$ in $\mathrm{KCl}=6.81)$; A2: Sopje pseudogley $(\mathrm{pH}$ in $\mathrm{KCl}=4.10)$

Table 2

Soil and genotype effects on cadmium concentrations in leaves of maize

(Kovačević et al., 2002)

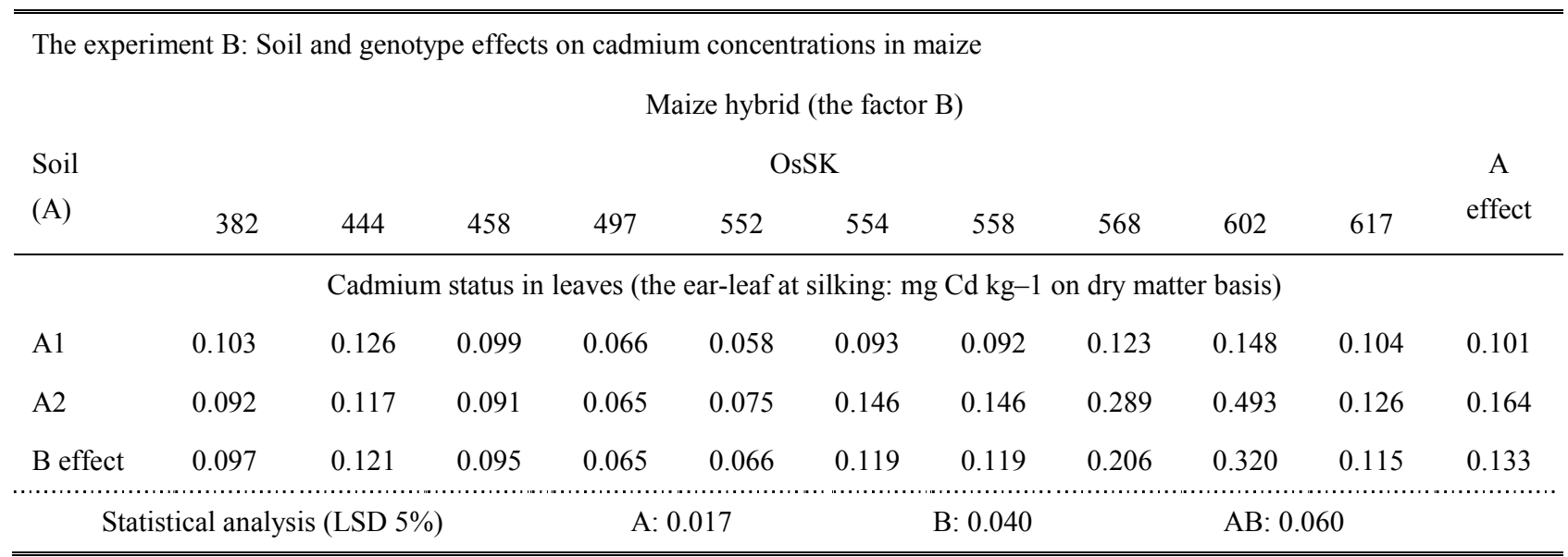

$\mathrm{A} 1$ : Zupanja calcaric fluvisol $(\mathrm{pH}$ in $\mathrm{KCl}=7.12)$; $\mathrm{A}$ : Luzani pseudogley $(\mathrm{pH}$ in $\mathrm{KCl}=5.17)$ 
Table 3

Impact of liming on cadmium status in plants

(Rastija et al., 2012b; Lončarić et al., 2012b; Kovačević and Loncaric, 2014)

\begin{tabular}{|c|c|c|c|c|c|c|c|c|c|c|c|c|c|}
\hline \multirow[b]{2}{*}{ Year* } & \multirow[b]{2}{*}{0} & \multicolumn{3}{|c|}{ Carbocalk $\left(\mathrm{t} \mathrm{ha}^{-1}\right)$} & \multicolumn{2}{|r|}{ LSD } & \multicolumn{6}{|c|}{ Carbocalk $\left(\mathrm{t} \mathrm{ha}^{-1}\right)$} & \multirow{2}{*}{$\begin{array}{l}\text { LSD } \\
5 \%\end{array}$} \\
\hline & & 15 & 30 & 45 & 60 & $5 \%$ & Year* & 0 & 15 & 30 & 45 & 60 & \\
\hline \multicolumn{7}{|c|}{ Leaf- $\mathrm{Cd} \mathrm{m} \mathrm{kg}^{-1}$ in dry matter } & \multicolumn{7}{|c|}{ Leaf-Cd mg kg ${ }^{-1}$ in dry matter } \\
\hline $2006 \mathrm{M}$ & 0.15 & 0.07 & 0.06 & 0.05 & 0.05 & 0.01 & $2005 \mathrm{~T}$ & 3.6 & 2.2 & 2.1 & 1.9 & 1.9 & 0.4 \\
\hline \multirow[t]{2}{*}{$2010 \mathrm{M}$} & 0.19 & 0.10 & 0.10 & 0.11 & 0.09 & 0.06 & $2008 \mathrm{~T}$ & 2.7 & 2.2 & 2.0 & 2.7 & 2.7 & ns \\
\hline & \multicolumn{6}{|c|}{ Grain-Cd in maize: $<0.02 \mathrm{mg} \mathrm{Cd} \mathrm{kg}^{-1}$} & $2011 \mathrm{~S}$ & 0.50 & 0.12 & 0.08 & 0.02 & 0.03 & 0.07 \\
\hline
\end{tabular}

* M: maize at silking stage, $\mathrm{T}$ : tobacco at the mid-season, $\mathrm{S}$ : soybean at beginning of anthesis

Table 4

Influences of liming on cadmium status of alfalfa (Rastija et al., 2012a)

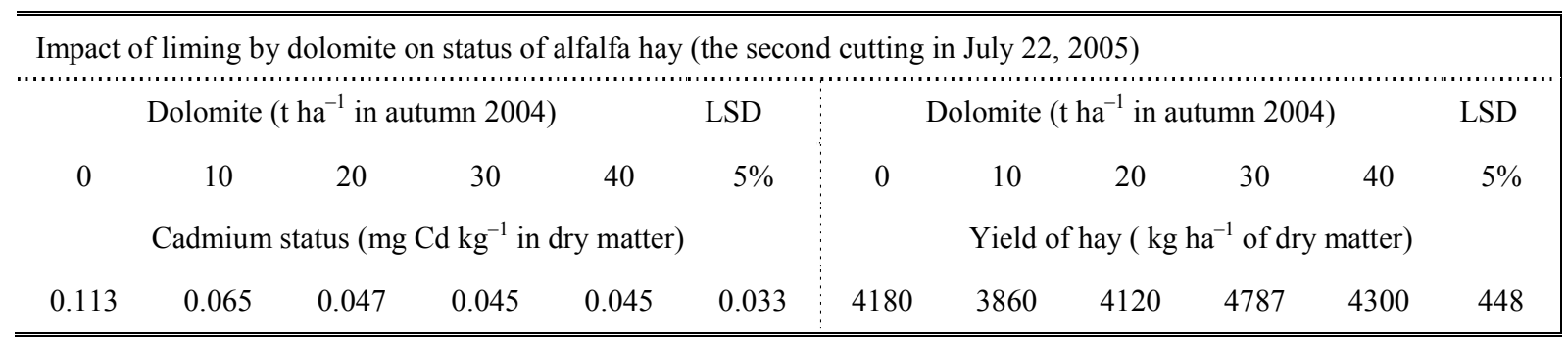

\section{CONCLUSIONS}

Very low concentrations of $\mathrm{Cd}$, mainly below $0.2 \mathrm{mg} \mathrm{Cd} \mathrm{kg}{ }^{-1}$ in dry matter of maize and soybean leaves were found under non-polluted environment of the eastern Croatia. With that regard, differences were found in maize leaves as affected by soil type and under neutral soil conditions $\mathrm{Cd}$ concentrations were considerably lower compared to acid environment. Also, $\mathrm{Cd}$ concentrations in maize grain were considerably lower (below detection limit: $0.02 \mathrm{mg} \mathrm{Cd} \mathrm{kg}^{-1}$ ) than in leaves. Beside environmental factors, heredity considerably affected $\mathrm{Cd}$ status in maize leaves and differences among tested hybrids under identical environmental conditions were higher compared to these differences among soil types.

Soil amelioration by liming had considerably effects on decreases of $\mathrm{Cd}$ concentrations in maize and soybean.

\section{REFERENCES}

[1] Antunović, M., Bukvić, G., Rastija, M.: Response of corn hybrids on two soil types of Slatina Podravina area. Poljoprivreda / Agriculture 8 (1), 15-19 (2002).

[2] Antunović, M., Kovačević, V., Rastija, M., Zdunić, Z.: Influences of soil and genotypes on micronutrients status in maize plants. Poljoprivreda / Agriculture 9 (1), 9-14 (2003).

[3] Antunović, M., Rastija M., Kovačević V.: Choice of maize hybrids for acid soils based on field experiments, Proceedings of the $6^{\text {th }}$ International Symposium on PlantSoil Interactions at Low $\mathrm{pH}$, Sendai, Japan (Matsumoto H. et al. Editors), August 1-5, 2004, Intern. Steering Committee on Plant-Soil Interactions at Low $\mathrm{pH}$ and Japanese Soc. of Soil Science and Plant Nutrition, pp. 350351, 2004.

[4] Bukvić, G., Jolankai, M., Josipović, M., Kovačević, V.: Harmful elements contents $(\mathrm{Sr}, \mathrm{Hg}, \mathrm{Pb}$ and $\mathrm{Cd}$ ) in soil and corn samples in the Eastern Croatia. In: 50 Eves a Magyar Hybrid Kukorica (Bedo Z. Ed.), Jubileumi tudomanyos ules (2003. szeptember 30.), A Magyar Tudomanyos Akademia Mezogazdasagi Kutatointezete, Martonvasar. Hungary, pp. 93-98 (2003).

[5] Godt, J., Scheiding, F., Grosse-Siestrup, C., Esche, E., Brandenburg, P., Reich A., Groneberg, D. A.: The toxici- 
ty of cadmium and resulting hazards for human health. Journal of Occupational Medicine and Toxicology, 2006. (http://www.occup.med./content/1/1/22).

[6] Jurković, Z., Josipović M., Drezner G., Jurković V., Banaj D.: Residual effects of liming with carbocalk on maize and wheat status. Cereal Research Communications 36 (Suppl.), 767-770 (2008).

[7] Kádár, I, Morvai, B., Szabó, L.: Phytotoxicity of heavy metals in long-term field experiments. In: Soil Pollution (Ed.: Gy. Filep), Agric. Univ. Debrecen, 1998, pp. 138143.

[8] Kádár, I., Koncz, J., Fekete, S.: Movement of Cd, Hg, Mo, $\mathrm{Pb}$ and $\mathrm{Se}$ in soil-plant-animal chain. In: ALPS-ADRIA Scientific Workshop Proceedings (Ed. Gyurica Cs.) Opatija. Croatia. HAS. MTA TAKI., Budapest, 2002, 9094.

[9] Kovačević, V., Antunović, M., Bukvić, G., Rastija, M., Kadar, I.: Soil and genotype influences on heavy metals status in maize. Ekologia (Bratislava) 23 (1), 65-70 (2004).

[10] Kovačević, V., Banaj, D., Kovačević, J., Lalić, A., Jurković, Z., Krizmanić, M.: Influences of liming on maize, sunflower and barley. Cereal Research Communications 34 (1), 553-556 (2006).

[11] Kovačević, V., Buhiniček, I., Vragolović, A., Havrda, S.: Influences of genotype and soil properties on $\mathrm{Ca}, \mathrm{Mg}, \mathrm{S}$, $\mathrm{Zn}, \mathrm{Mn}, \mathrm{B}, \mathrm{Mo}, \mathrm{Sr}, \mathrm{Ba}$ and $\mathrm{Cd}$ status in maize inbreds, Modern variety breeding for present and future needs Proceedings of the 18th EUCARPIA General Congress, 9-12 Sept. 2008 Valencia, Spain. (Eds. Prohens, J. and Badenes, M. L.), Editorial Universidad Politecnica de Valencia, Spain, 2008, pp. 607-612.

[12] Kovačević, V., Kádár, I., Drezner, G., Banaj, D., Rékási, M.: Residual impacts of liming on wheat yield, Proceedings of $45^{\text {th }}$ Croatian and $5^{\text {th }}$ International Symposium of Agriculuture, Opatija 15-19 February 2010 (Maric, S. and Loncaric, Z. Eds), Faculty of Agriculture in Osijek, 2010, pp. 801-803.

[13] Kovačević, V., Kádár, I., Koncz, J.: Soil and genotype influences on cadmium and strontium status in maize plants. Poljoprivreda / Agriculture 8 (2), 25-28 (2002).

[14] Kovačević, V., Lončarić, Z.: Using of carbocalk for improvement of soil fertility. Technologica Acta 7 (1), 1-8 (2014).

[15] Kovačević, V., Rastija, D., Sudar, R., Iljkić, D.: Učinak kalcizacije karbokalkom na tlo, prinos i kvalitetu zrna kukuruza. Glasnik zaštite bilja, 56 (6), 54-60 (2012a).
[16] Kovačević,V., Simić, D., Lončarić, Z., Kadar, I.: Hereditary and environmental effects on cadmium status in maize plants, Safe Food, Proceedings of the $16^{\text {th }}$ International Eco-Conference (Aleksić, N., Ed.), 26-29 Sept. 2012, Novi Sad, Serbia, Ecological Movement of Novi Sad, 2012b, pp. 87-96.

[17] Lončarić, Z., Popović, B., Karalić, K., Jurković, Z., Nevistić, A., Engler, M.: Soil chemicals properties and wheat genotype impact on micronutrient and toxic elements content in wheat integral flour. Medicinski glasnik, 9: 97-103 (2012a).

[18] Lončarić, Z., Rastija, D., Kadar, I., Kovačević, V.: Effects of liming on cadmium concentrations in the field crops, Compedium of Abstracts, $8^{\text {th }}$ International Symposium on PSILPH (Plant-Soil Interactions at Low pH, 18 22. Oct. 2012. Bengaluru, India, (Editors Prakash N. B., Parama Ramakrishna V. R., Satish A., et al.), University of Agricultural Sciences, Bengaluru, 2012b, pp. 234-235.

[19] Pinto, A. P., Mota, A. M., De Varennes, A., Pinto, F. C.: Influence of organic matter on the uptake of cadmium, zinc, copper and iron by sorghum plants, Science Total Environment 326, 239-247 (2004).

[20] Popović, S., Tučak, M., Knezović, Z.: Response of alfalfa to liming. Cereal Research Communications, 36 (2), 941944 (2007).

[21] Rastija, D., Popović, S., Rastija, M., Tučak, M.: Liming effects on yield of alfalfa hay and toxic metals concentrations, Safe Food, Proceedings of the $16^{\text {th }}$ International Eco-Conference (Aleksić N., Editor), 26 - 29 Sept. 2012, Novi Sad, Serbia, Ecological Movement of Novi Sad, 2012a, pp. 219-224.

[22] Rastija, M., Sudarić, A., Kovačević, V., Iljkić, D., Varga, I.: Impacts of liming on yield, protein contents and cadmium status of soybean, Safe Food, Proceedings of the $16^{\text {th }}$ International Eco-Conference (Aleksić N., Editor), 26-29 Sept. 2012, Novi Sad, Serbia, Ecological Movement of Novi Sad, 2012b, pp. 243-250.

[23] Stingu, A., Stanescu, I., Volf, I., Popa, V.: Hyperaccumulation of cadmium in maize plant (Zea Mays). Cellulose Chem. Technol. 45 (3-4), 287-290 (2011).

[24] Tursić, I., Kovačević, V., Banaj, D., Husnjak, S., Zalac S.: Influences of liming on the heavy metal contents in tobacco leaves. In: Proc. 17th Intern. Symp. Of CIEC, 24-27 Nov. 2008, NRC (Micronutrient Project), Cairo, Egypt, 2008, pp. 53-57. 